\title{
Non-classical role of Galectin-3 in cancer progression: translocation to nucleus by carbohydrate-recognition independent manner
}

\author{
Seok-Jun Kim ${ }^{1,2}$ E Kyung-Hee Chun ${ }^{3,4, *}$ \\ ${ }^{1}$ Department of Biomedical Science, College of Natural Science, Chosun University, ${ }^{2}$ Department of Life Science \& Brain Korea 21 Plus \\ Research Team for Bioactive Control Technology, Chosun University, Gwangju 61452, ${ }^{3}$ Department of Biochemistry \& Molecular Biology, \\ Yonsei University College of Medicine, ${ }^{4}$ Brain Korea 21 PLUS Project for Medical Science, Yonsei University College of Medicine, Seoul \\ 03722, Korea
}

\begin{abstract}
Galectin-3 is a carbohydrate-binding protein and regulates diverse functions, including cell proliferation and differentiation, mRNA splicing, apoptosis induction, immune surveillance and inflammation, cell adhesion, angiogenesis, and cancer-cell metastasis. Galectin-3 is also recommended as a diagnostic or prognostic biomarker of various diseases, including heart disease, kidney disease, and cancer. Galectin-3 exists as a cytosol, is secreted in extracellular spaces on cells, and is also detected in nuclei. It has been found that galectin-3 has different functions in cellular localization: (i) Extracellular galectin-3 mediates cell attachment and detachment. (ii) cytosolic galectin-3 regulates cell survival by blocking the intrinsic apoptotic pathway, and (iii) nuclear galectin-3 supports the ability of the transcriptional factor for target gene expression. In this review, we focused on the role of galectin-3 on translocation from cytosol to nucleus, because it happens in a way independent of carbohydrate recognition and accelerates cancer progression. We also suggested here that intracellular galecin- 3 could be a potent therapeutic target in cancer therapy. [BMB Reports 2020; 53(4): 173-180]
\end{abstract}

\section{INTRODUCTION}

Galectin-3, as a member of the galectin family, which are recognized $\beta$-galactoside-containing glycoconjugates by means of carbohydrate-recognition domain (CRD) $(1,2)$. Based on molecular structure, galectin family consists of the 15 members and these family are divided into three main groups: 1)

*Corresponding author. Tel: +82-2-2228-1699; Fax: +82-2-312-5041; E-mail: khchun@yuhs.ac

https://doi.org/10.5483/BMBRep.2020.53.4.020

Received 20 January 2020

Keywords: Cancer progression, Carbohydrate-binding, Cellular localization, Galectin-3 prototype group (Galectin-1, -2, -5, -7, -10, -11,-13, -14, and $-15), 2$ ) tandem repeat group (galectin-4, $-6,-8,-9$, and -12 ), and 3) chimera type (galectin-3) (1, 3-6). Whereas prototype galectins are mostly homodimers with two polypeptides each containing a CRD, the tandem repeat galectins have two CRDs, connected by a linker region $(1,4,5)$. Chimeric galectin-3 consist of one CRD connected to an extended Proline-GlycineTyrosine tandem repeats region and an $\mathrm{N}$-terminal proline and glycine rich domain $(3,5)$. Galectin family are present in a various tissues, whereas others have a more specific location (1). Galectins have many functions, such as cell proliferation and differentiation, immune response, apoptosis, cancer progression, and metastasis $(4,7)$. The mechanisms underlying these aspects are currently the focus of massive research projects.

Galectin-3 is the only chimera type in animal lectins. Also, galectin-3 is one of the most studied of the galectin family, (8-10). It is a versatile 29-35 kDa protein, as an involved in multiful biological processes followed in cellular location: cell adhesion, cell growth and differentiation, the cell cycle, and apoptosis $(1,11,12)$. Galectin-3 is situated on chromosome 14 , locus $\mathrm{q} 21-\mathrm{q} 22$ which is coded by a single gene LGALS3 (13). LGALS3 gene promoter region have a several regulatory elements, like a Sp1 binding sites, AP-1 complex, cAMPdependent response element (CRE) motifs, and two NF-kB-like sites $(10,11)$. Galectin-3 mainly exists in the cytosol and is secreted out to the extracellular membrane (ECM) (14), but galectin-3 is also reported in the nucleus and mitochondria (9, 15).

In galectin family, it is known that there is no signal peptide to guide you through the classical secretion pathway. In particular, galectin-3 to go in extracellular space can interact with multiple binding partners or generality polylactosamine-rich molecules in the extracellular matrix (ECM) or on the surface of cells, and plays a major role in the extracellular regulation of various cancer progression $(5,16,17)$. The non-classical secretion mechanism for galectin-3 remains unclear, but recently acquired data show that the secreted galactin-3 is regulated by

ISSN: 1976-670X (electronic edition)

Copyright (C) 2020 by the The Korean Society for Biochemistry and Molecular Biology

(c) This is an open-access article distributed under the terms of the Creative Commons Attribution Non-Commercial License (http://creativecommons.org/licenses/by-nc/4.0) which permits unrestricted non-commercial use, distribution, and reproduction in any medium, provided the original work is properly cited. 
exosomes (18) and that the $\mathrm{N}$-terminal domain serves to position the galactin-3 in these structures $(6,10,19)$.

Galectin-3 is also present in the nucleus and cytosol. Especially, depending on the various cell types and specific experimental conditions, galectin-3 has been reported to be predominantly located in the cytosol and nuclei or distributed between the two subcellular compartments $(1,20)$. Many articles have supported galectin-3 localization, transport, and association with the interaction of distinct subcellular components $(1,20)$.

Through the in this review, we were described brief overview of the intracellular galectin-3 functions in cancer progression that are independent of carbohydrate recognition and nucleus or cytoplasmic shuttling.

\section{REGULATION OF GALECTIN-3 EXPRESSION IN CANCERS}

Despite of expression of galectin-3 in various of tissues and cell types, and their involvement in various human diseases, this molecule is of particular interest due to its remarkable role in controlling cancer progression $(21,22)$. Galectin-3 is often high expressed in various solid and malignant tumors, and this case is generally correlated with the progression of cancer, suggesting that this molecule plays an important role in disease outcome $(4,5)$. In particular, the expression of galectin-3 in cells is characterized by the following malignant cell transformation (23), tumor growth (24), cell adhesion (25), anoikis resistance $(26,27)$, pro- or anti-apoptosis (28-30), angiogenesis (31-33), and cell motility (34-36) have been reported. Galectin-3 expression may also be a potential biomarker of various cancers (37). Interestingly, expression of galectin-3 was implicated in many cancers $(16,38)$. Especially, highly expression of galectin-3 was detected in stomach, liver, esophagus, thyroid, and pancreas cancers $(23,39-44)$. This highly expressed galectin-3 is correlated with cancer progression or metastatic potential in various cancers $(38,45)$. However, contradictory results have also been reported, in which the expression of galectin-3 was significantly reduced in breast, prostate and endometrial cancers (46-49). In addition, expression of galectin-3 has also been reported to be up-regulated at an early stage of intrahepatic cholangiocarcinoma and down-regulated at later stage of intrahepatic cholangiocarcinoma (50). Also, galectin-3 translocation from the nucleus to the cytoplasm during prostate carcinoma was observed (51). This implies that decreased galectin-3 expression may be associated with alterations in cytoplasm / nucleus expression patterns and provides a reason why studies on translocation as well as the expression of galectin-3 in various carcinomas should be continued.

According to many reports, galectin-3 is not a common and obvious marker for various cancers, but it can be a useful parameter for diagnosis many tumors. Also, both transcriptional and translational galectin-3 expression was regulated by various stimulations and ligands. In addition, numerous factors have an effect on the complex regulatory mechanism of galectin-3
$(1,7)$. For example, the expression of galectin-3 in adenoma that prolactin and adrenocorticotropic hormone (ACTH) in the pituitary gland and other tumors is associated with the galectin-3's promoter methylation status of the galectin-3 (52). Also, regulatory mechanism of galectin-3 expression is not directly induced by certain factors, but the cellular differentiation state or tissue type has been involved. Moreover, various transcription factors, as a RUNX (rent-related protein) family, nuclear factor $\mathrm{kB}(\mathrm{NF}-\mathrm{kB})$, homeodomain-interacting protein kinase 2 (HIPK2), and many intracellular signal pathways, such as Wnt and Notch signaling, are regulated in the regulation of galectin-3 expression (11, 53-56).

\section{MECHANISM OF NUCLEUS AND CYTOPLASMIC GALECTIN-3 SHUTTLING}

Nucleus and cytoplasmic shuttling is generally reported as the repeated bi-directional movement of proteins across nuclear pore complex $(7,20,57)$. Both nucleus and cytoplasmic shuttling of galectin-3 reported by means of the many articles $(57,58)$. The galectin-3 movement between the nucleus and the cytoplasm has been the focus of attention for years $(7,17$, 20 ). This is because the shuttle of galectin- 3 from the nucleus to the cytoplasm is necessary because it protects certain cells from stress challenges $(20,57)$. Especially, the $\mathrm{N}$-terminal area containing the phosphorylated $\mathrm{Ser}^{6}$ site, plays an important role in nuclear transport because the mutation in the Ser $^{6}$ interferes with the export of galectin-3 by cytoplasm $(1,12$, 59). CRD of galectin-3 is important for carbohydrate bonding, but this structural domain is also important for galectin-3 localization in cells $(1,7,12)$. Recently, galectin-3 is seen as an important nuclear protein, which may be evidenced by the discovery of both nuclear import sequences (nuclear localization sequence; NLS) and nuclear export sequences (NES) sequences within the CRD (Fig. 1) (1, 4, 20). The combination with Importin $\alpha$ is very important for the movement of galectin-3 but the Importin $\alpha / \beta$ complex is necessary for the transport of galecin-3 $(60,61)$. Also, export of galectin-3 is known to rely on the binding to Nucleoporin 98 (Nup98), and the Nup98:XPO1 complex is involved in the nuclear migration of galectin-3 (62).

Also, a mutation of galectin-3 at position 64 of amino-acid (rs4644) substituting proline for histidine (gal-3 $\mathrm{H}^{64}$ ) increased nuclear galectin-3 in breast and gastric cancers $(63,64)$. Moreover, gal- $3 \mathrm{H}^{64}$ enhances gastric cancer progression more

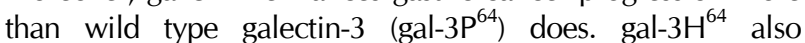
increased both nuclear accumulation of $\beta$-catenin and expression of TCF- 4 target genes, such as fascin- 1 and c-Myc, by means of the augmented promoter-binding activity of TCF-4 more than did gal-3P $\mathrm{P}^{64}$ (63). Thus, galectin-3 shuttling was regulated by the domain or mutation in various cancers and was involved in cancer progression. 


\begin{tabular}{|c|c|c|}
\hline 12 & 115 & 250 \\
\hline NTR & PGAY repeat motif & CDR (135aa) \\
\hline \multirow[t]{3}{*}{$S^{6}$} & $\mathrm{p}^{64}$ : mutation & NWGR : BCL-2 binding motif \\
\hline & $S^{96}:$ GSK-3 $\beta$ binding site & NHRVKKLNE: NLS-like sequence \\
\hline & $\mathrm{Rb}$ binding site (1-110aa) & LNEISKLGI : NES \\
\hline & binding site (1-62aa) & N1ICD binding site (111-250aa) \\
\hline
\end{tabular}

Fig. 1. Structure of galectin-3. Galectin-3 consists of an N-terminal Domain (NTD), which has an N-terminal Region of 12 amino acids (aa) and a PGAY repeat motif (12-115aa). The carbohydrate-recognition domain (CRD) 130 aa comprises the C-terminal. Each domain describes a binding motif and signaling pathway.

\begin{abstract}
Apoptosis regulated by galectin-3 interacts with carbohydrate recognition independent manner

Galectin-3 involved in diverse signal-transduction cascades and pro- or anti-survival processes. Actually, phosphorylated galectin-3 is required for anti-apoptotic activity and for phosphorylation regulated by carbohydrate recognition $(9,12,17)$. However, those anti-apoptotic functions of galectin-3 were regulated by non-carbohydrate recognition. It was proved that galectin-3 interacts $\mathrm{Bcl}-2$ (28). Although galectin-3 is not a member included in the $\mathrm{Bcl}-2$ family, interestingly, these galectin-3 and $\mathrm{Bcl}-2$ genes have significant sequence similarity (48\% protein sequence similarity) (28). Especially, CRD region of galectin-3 have a four-amino-acid motif, as an Asn-Trp-GlyArg (NWGR) (amino-acid residues 180-183), which motif is highly conserved in Bcl-2 family's BH-1 domain (amino-acid residues 143-146 in Bcl-2 gene) $(12,28)$. Moreover, galectin-3 is the only member that contains the NWGR motif in the galectin family and that acts as an anti-apoptotic molecule in intracellular localization. Therefore, the NWGR motif in CRD of galectin-3 is closely involved in anti-apoptotic process through interaction with $\mathrm{BCl}-2$. However, galectin-3 regulates apoptosis by means of the cytochrome $\mathrm{c}$ release and cell-cycle regulation.
\end{abstract}

Cancer progression and cell motility regulated by galectin-3 interacts with carbohydrate recognition independent manner As mentioned in the introduction, galectin-3 has many roles in various cancers, such as splicing (65), cell proliferation (66), regulation of the cell cycle (26), angiogenesis (33), tumorigenesis (67), and cancer metastasis (68). It has also been demonstrated to be highly expressed in various primary and metastatic tumors (69) associated with increased cancer progression, cell motility, and metastasis $(4,70)$. Actually, galectin-3 binding with transcription factor (TF) in the nucleus by means of the following signaling pathway, such as Wnt, Ras, or MEK, as followed various cancer progression $(1,4)$. In this part, we showed that the role of galectin-3 in cancer progression and cell motility with regulation of gene transcription focuses on our galectin-3-related story.

Galectin-3 and Fascin-1: For the cancer progression and cell motility with galectin-3, we focus on motility-related genes, among which fascin-1, an actin-bundling protein, is located along the entire length of filopodia in cells $(71,72)$. Because (a) a highly expressed fascin- 1 was reported in various cancers including gastric, lung, and esophagus cancers (73-75). (b) Increased fascin-1 induces membrane protrusions and increases cancer cell motility (76). (c) Depletion of fascin-1 leads to a substantially reduced number of filopodia and overexpression of fascin-1, significantly increasing cell migration $(74,77,78)$. Especially, fascin-1 expression is regulated by the Wnt-signaling pathway. As previously reported, galectin-3 was also reported to interact with GSK-3b and b-catenin which is regulate Wnt signaling (79). Therefore, galectin-3 regulates b-catenin nuclear accumulation via strongly interacting with GSK-3b and the binding of b-catenin/TCF-4 to promoter region of fascin-1 (Fig. 2) (35). Those studies propose that galectin-3 is involved in gastric-cancer metastasis and a critical therapeutic target for the cancer prevention.

Galectin-3 and Protease-activated receptor-1 (PAR-1), Matrix Metalloprotease (MMP)-1: PAR-1, a cell-surface receptor, is a member of the family of transmembrane G-protein-coupled receptors (80). Activated PAR-1 is initiated by cleavage at its $\mathrm{N}$ terminus exodomain between Arg41 and Ser42, and autophosphorylates to trigger amplification of downstream signaling by proteases (80-83), such as thrombin or MMP-1 derived from stroma (84). PAR-1 and MMP-1 were related in cancer progression and cell motility. Interestingly, up-regulation of PAR-1 and MMP-1 via c-Jun and Fra-1 over-expression also followed, AP-1 complex, as a c-Jun and Fra-1, were direct interaction of galectin-3 (Fig. 2). It was previously reported that galectin-3 regulates $\mathrm{MUC2}$ expression via interaction with $\mathrm{AP}-1$, leading to its activation, and the site of formation of complexes was hypothesized to be AP-1 on the MUC2 promoter (85). Those results also support about galectin-3 regulates cancer progression and motility.

Galectin-3 and Neogenin-1: Neogenin-1 is a transmembrane receptor, as a member of immunoglobulin superfamily (86). Although neogenin- 1 has significant sequence similarity $(50 \%$ amino-acid identity) with the tumor suppressor molecule deleted in colon cancer (DCC) (86), but the expression is increased in gastric cancer patients (87). Also, neogenin-1 is enhanced in cancer proliferation and cell motility (87). Actually, expression of neogenin-1 is regulated by heat shock factor-1 (HSF-1). Moreover, galectin-3 promotes gastric-cancer 


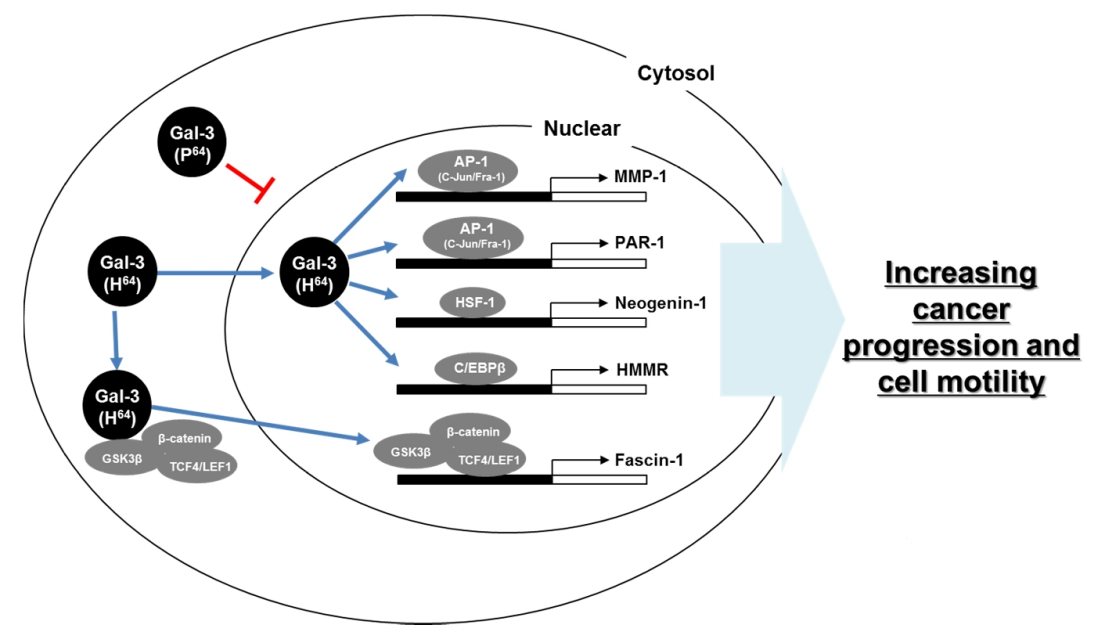

Fig. 2. Schematic model of mechanism of galectin-3 in cancer progression and metastasis. Galectin-3 bound various transcription factors, such as AP-1, HSF-1, C/EBP $\beta$, and TCF4/LEF1, and regulates cancer progression and cell motility.

cell motility by means of up-regulation of neogenin- 1 expression by means of the induced phosphorylation of ROCK1(87). Additionally, galectin-3 induced accumulation of HSF-1 in nuclei by means of direct binding (Fig. 2). Those data suggest that galectin-3 is involved in cancer progression.

Galectin-3 and Hyaluronan-mediated motility receptor (HMMR): At last, HMMR binds with hyaluronan on the cell surface, where it activates a signal-transduction cascade causing intracellular protein tyrosine phosphorylation $(88,89)$. In addition, HMMR interacts with actin filaments, microtubules, and mitotic spindle assemblies, necessary for the organization of the cytoskeletal network $(88,90-92)$. These HMMRs are regulated by interaction between the transcriptional factor CCAAT/ enhancer-binding protein $\mathrm{b}(\mathrm{C} / \mathrm{EBPb})$ and galectin-3 (36). Also, $\mathrm{C} / \mathrm{EBPb}$ is regulated by galectin-3BP (galectin-3 binding protein) and promotes tumor progression in various cancers (Fig. 2) (93-95). These data mean galectin-3 binds with transcription factor in nuclei and regulates cancer progression and metastasis.

\section{Senescence regulated by galectin-3 interacts with carbohydrate recognition independent manner}

By means of the aberrant activation of oncogenes, such as Ras and Myc, or excessive mitogenic signals, can enhance senescence by means of two different pathways, $\mathrm{p} 14^{\mathrm{ARF}} / \mathrm{p} 53 / \mathrm{p} 21$ or $\mathrm{p} 16^{\mathrm{INK} 4 \mathrm{~A}} / \mathrm{pRB}$ (96). However, galectin-3 knock-out (KO) mouse embryo fibroblasts (MEF) and silenced galectin-3 gastric-cancer cells showed that galectin-3 relies on $\mathrm{p} 27^{\mathrm{KIP}}$, not $\mathrm{p} 21^{\mathrm{wAF} 1 / \mathrm{CIP} 1}$, to regulate premature senescence without oncogenic stress (97). Actually, the N-terminal of galectin-3 (amino-acid residues 1-110), bound with $\mathrm{Rb}, \mathrm{E} 2 \mathrm{~F} 1$, as a transcription factor of SKP2, was released from $\mathrm{Rb}$ and initiated its transcriptional functions (Fig. 1) (97). Increased
SKP2 regulates $\mathrm{p} 27^{\mathrm{KIP} 1}$ degradation. Based on the research, galectin-3 prevents premature senescence by means of interaction and phosphorylation of $\mathrm{Rb}$ and consequent regulation of SKP2 and p2 $7^{\mathrm{KIP} 1}$ expression. Moreover, galectin-3 bound to human Telomerase Reverse Transcriptase (hTERT) is an important factor of tumorigenesis and senescence (98). Especially, hTERT plays an important role in the regulation of telomerase activity in cell division, which is responsible for immortalized cell growth. The hTERT was binding with the $\mathrm{N}$-terminal of galectin-3 (amino-acid residues 1-62) and increased telomeric activity (Fig. 1) (98). This evidence will show that galectin-3 regulates cellular senescence by means of the related genes interaction.

\section{Cancer stemness regulated by galectin-3 interacts with carbohydrate recognition independent manner}

Cancer Stem Cells (CSCs) are a malignant and aggressive cancer phenotype and have been increasingly studied over the last decade. These cells are derived from more differentiated cancer cells, potentially acquiring self-renewal properties and the ability to undergo epithelial-mesenchymal metastasis (EMT). Recently, galectin-3 expression increased in tumor sphere formation in cancer cells, together with stem-cell markers Oct4, Sox2, Nanog, CD133, and CXCR4 (99). Those mean galectin-3 is involved in the stemness of cancer cells. Especially, galectin-3 binds with EGF and bFGF (99) as a component of stem-cell culture medium and regulates KLF4 expression with miRNA-152 (100). These results support that galectin-3 is involved in cancer stemness. Also, galectin-3 supports stemness by signaling pathway regulation. Galectin-3 was essential for cluster formation using $\alpha v \beta 3$ integrin and KRAS to activate the NF-kB pathway and stemness (101). Also, the Wnt, Notch, and $\mathrm{SHH}$ signaling pathways can help CSCs properties from 
normal stem cells. Among the signaling pathways, the Notch 1 intra-cellular domain (N1ICD) interacts with CRD of galectin-3 (amino-acid residues 111-250) (Fig. 1) in the cytoplasm of ovarian cancer cells (55). Moreover, galectin-3 is interaction with $\beta$-catenin, as a component Wnt signaling pathway, in the cytoplasm and help to nuclear accumulation in the gastric cancer cells $(35,63)$. The above results suggest that galectin-3 regulates cancer stemness by means of the various interaction molecules, not only carbohydrates.

\section{PERSPECTIVES: GALECTIN-3 IS A POTENTIAL THERAPEUTIC TARGET FOR CANCER PROGRESSION}

Among current research on the role of galectin-3, the prognosis value of cancer patients still needs to be discussed $(5,102)$. Nevertheless, the expression of galectin-3 was proved to be a useful parameter for the diagnosis and/or prognosis of various cancers. $(21,38,103)$. Therefore, many researchers have attempted to develop new approaches for the diagnosis and treatment of cancer by galectin-3 targeting. First, transfected galectin-3 antisense cDNA decreases in the malignant phenotype of thyroid gland cancer cells (104). Numerous studies have focused on the galectin-3 targeting inhibitors, including peptide antagonists (105) and galactose-based inhibitors $(106,107)$. Also, in addition to these synthetic molecules, a natural product, pectin, has emerged as a good source for generating high-affinity galectin-3 inhibitors with low toxicity. Recently, a wide range of sub-molecular inhibitors have been considered (108). Among these, a new kind of galectin-3 inhibitor, which contains only one residue of sugar (109) that constitutes membrane permeability and oral available powerful galectin-3 inhibitor has been developed.

\section{CONCLUSION}

Highly expressed galectin-3 is detected in various cancers and tissues, and is involved in many biological processes, like a cell proliferation, adhesion, anti- or pro-apoptosis, cancer progression, and metastasis. Therefore, galectin-3 is enhanced in cancer progression and metastasis by means of different mechanisms. Also, the biological function of galectin-3 were attributed to each carbohydrate-binding activity. However, many articles showed that galectin-3 interacts with many molecules by non-carbohydrate binding. In this review, we focus on the regulation mechanism with nucleus and cytoplasmic shuttling and the role of nuclear galectin- 3 in cancer progression. Especially, galectin-3 has an NLS and NES; however, galectin-3 mutation also helps the galectin-3 shuttling nucleus and cytosol. As follows, galectin-3 has many functions in each location. Additionally, galectin-3 is involved in cancer progression and metastasis by means of the binding with transcription factor, such as AP-1 complex (c-Jun/Fra-1), HSF-1, C/EBP $\beta$, and TCF4/LEF1. Also, recently many articles supported about multifunction of galectin-3 in various cancers and other diseases.
Those increased understanding evidences give to the galectin-3 expression or activity regulation mechanism for therapeutic purposes. Given these results, we propose that galectin-3 is a core protein in cancer progression and metastasis. In addition, the function of galectin- 3 and the mechanisms by which it can be regulated should be understood in detail.

\section{ACKNOWLEDGEMENTS}

This work was supported by from the National Research Foundation (NRF) of Korea grants, funded by the Korean government (NRF-2017R1C1B2005265, NRF-2017R1A2B200 6238, NRF-2019R1A2C2089237), the Bio \& Medical Technology Development Program, MSIP (NRF-2015M3A9B6073835), KBRI basic research program through Korea Brain Research Institute funded by Ministry of Science and ICT(20-BR-03-02), and the International Research \& Development Program of the NRF, funded by the Ministry of Education, Science and Technology (MEST) of Korea (NRF-2016K1A3A1A47921595).

\section{CONFLICTS OF INTEREST}

The authors have no conflicting interests.

\section{REFERENCES}

1. Dumic J, Dabelic S and Flogel M (2006) Galectin-3: an open-ended story. Biochim Biophys Acta 1760, 616635

2. Leffler $H$, Carlsson $S$, Hedlund $M$, Qian $Y$ and Poirier $F$ (2002) Introduction to galectins. Glycoconj J 19, 433-440

3. Drickamer K and Fadden AJ (2002) Genomic analysis of C-type lectins. Biochem Soc Symp 69, 59-72

4. Liu FT and Rabinovich GA (2005) Galectins as modulators of tumour progression. Nat Rev Cancer 5, 29-41

5. Fortuna-Costa A, Gomes AM, Kozlowski EO, Stelling MP and Pavao MS (2014) Extracellular galectin-3 in tumor progression and metastasis. Front Oncol 4, 138

6. Hirabayashi J and Kasai K (1993) The family of metazoan metal-independent beta-galactoside-binding lectins: structure, function and molecular evolution. Glycobiology 3, 297-304

7. Johannes L, Jacob R and Leffler H (2018) Galectins at a glance. J Cell Sci 131

8. Argueso P and Panjwani N (2011) Focus on molecules: galectin-3. Exp Eye Res 92, 2-3

9. Ruvolo PP (2016) Galectin 3 as a guardian of the tumor microenvironment. Biochim Biophys Acta 1863, 427-437

10. Kadrofske MM, Openo KP and Wang JL (1998) The human LGALS3 (galectin-3) gene: determination of the gene structure and functional characterization of the promoter. Arch Biochem Biophys 349, 7-20

11. Wang $L$ and Guo XL (2016) Molecular regulation of galectin-3 expression and therapeutic implication in cancer progression. Biomed Pharmacother 78, 165-171

12. Krzeslak A and Lipinska A (2004) Galectin-3 as a multifunctional protein. Cell Mol Biol Lett 9, 305-328 
13. Raimond J, Zimonjic DB, Mignon C et al (1997) Mapping of the galectin-3 gene (LGALS3) to human chromosome 14 at region 14q21-22. Mamm Genome 8, 706-707

14. Hughes RC (1999) Secretion of the galectin family of mammalian carbohydrate-binding proteins. Biochim Biophys Acta $1473,172-185$

15. Yu F, Finley RL Jr, Raz A and Kim HR (2002) Galectin-3 translocates to the perinuclear membranes and inhibits cytochrome $\mathrm{c}$ release from the mitochondria. A role for synexin in galectin-3 translocation. J Biol Chem 277, 15819-15827

16. van den Brule F, Califice S and Castronovo V (2002) Expression of galectins in cancer: a critical review. Glycoconj J 19, 537-542

17. Ochieng J, Furtak V and Lukyanov P (2002) Extracellular functions of galectin-3. Glycoconj J 19, 527-535

18. Inohara $\mathrm{H}$ and Raz A (1994) Identification of human melanoma cellular and secreted ligands for galectin-3. Biochem Biophys Res Commun 201, 1366-1375

19. Yang RY, Rabinovich GA and Liu FT (2008) Galectins: structure, function and therapeutic potential. Expert Rev Mol Med 10, e17

20. Haudek KC, Spronk KJ, Voss PG, Patterson RJ, Wang JL and Arnoys EJ (2010) Dynamics of galectin-3 in the nucleus and cytoplasm. Biochim Biophys Acta 1800, 181-189

21. Thijssen VL, Heusschen R, Caers J and Griffioen AW (2015) Galectin expression in cancer diagnosis and prognosis: A systematic review. Biochim Biophys Acta 1855, 235-247

22. Ebrahim AH, Alalawi Z, Mirandola L et al (2014) Galectins in cancer: carcinogenesis, diagnosis and therapy. Ann Transl Med 2, 88

23. Takenaka Y, Inohara H, Yoshii T et al (2003) Malignant transformation of thyroid follicular cells by galectin-3. Cancer Lett 195, 111-119

24. Markowska Al, Jefferies KC and Panjwani N (2011) Galectin-3 protein modulates cell surface expression and activation of vascular endothelial growth factor receptor 2 in human endothelial cells. J Biol Chem 286, 2991329921

25. Hughes RC (2001) Galectins as modulators of cell adhesion. Biochimie 83, 667-676

26. Kim HR, Lin HM, Biliran H and Raz A (1999) Cell cycle arrest and inhibition of anoikis by galectin-3 in human breast epithelial cells. Cancer Res 59, 4148-4154

27. Zhao Q, Barclay M, Hilkens J et al (2010) Interaction between circulating galectin-3 and cancer-associated MUC1 enhances tumour cell homotypic aggregation and prevents anoikis. Mol Cancer 9, 154

28. Yang RY, Hsu DK and Liu FT (1996) Expression of galectin-3 modulates T-cell growth and apoptosis. Proc Natl Acad Sci U S A 93, 6737-6742

29. Harazono $Y$, Kho DH, Balan $V$ et al (2014) Galectin-3 leads to attenuation of apoptosis through Bax heterodimerization in human thyroid carcinoma cells. Oncotarget 5, 9992-10001

30. Nakahara S, Oka N and Raz A (2005) On the role of galectin-3 in cancer apoptosis. Apoptosis 10, 267-275

31. Nangia-Makker P, Wang Y, Raz T et al (2010) Cleavage of galectin-3 by matrix metalloproteases induces angiogenesis in breast cancer. Int J Cancer 127, 2530-2541

32. Wang LF, Liu YS, Yang B et al (2018) The extracellular matrix protein mindin attenuates colon cancer progression by blocking angiogenesis via Egr-1-mediated regulation. Oncogene 37, 601-615

33. Nangia-Makker P, Honjo $Y$, Sarvis R et al (2000) Galectin-3 induces endothelial cell morphogenesis and angiogenesis. Am J Pathol 156, 899-909

34. Kim SJ, Shin JY, Lee KD et al (2011) Galectin-3 facilitates cell motility in gastric cancer by up-regulating protease-activated receptor-1 (PAR-1) and matrix metalloproteinase-1 (MMP-1). PLoS One 6, e25103

35. Kim SJ, Choi IJ, Cheong TC et al (2010) Galectin-3 increases gastric cancer cell motility by up-regulating fascin-1 expression. Gastroenterology 138, 1035-1045 e1031-1032

36. Kang HG, Kim WJ, Kang HG, Chun $\mathrm{KH}$ and Kim S (2020) Galectin-3 interacts with C/EBPbeta and upregulates hyaluronan-mediated motility receptor expression in gastric cancer. Mol Cancer Res 18, 403-413

37. Dong R, Zhang M, Hu Q et al (2018) Galectin-3 as a novel biomarker for disease diagnosis and a target for therapy (Review). Int J Mol Med 41, 599-614

38. Califice S, Castronovo V and Van Den Brule F (2004) Galectin-3 and cancer (Review). Int J Oncol 25, 983-992

39. Baldus SE, Zirbes TK, Weingarten $M$ et al (2000) Increased galectin-3 expression in gastric cancer: correlations with histopathological subtypes, galactosylated antigens and tumor cell proliferation. Tumour Biol 21, 258-266

40. Volante M, Bozzalla-Cassione F, Orlandi F and Papotti M (2004) Diagnostic role of galectin-3 in follicular thyroid tumors. Virchows Arch 444, 309-312

41. Gudowska M, Gruszewska E, Cylwik B et al (2015) Galectin-3 Concentration in Liver Diseases. Ann Clin Lab Sci 45, 669-673

42. Inufusa $H$, Nakamura $M$, Adachi $T$ et al (2001) Role of galectin-3 in adenocarcinoma liver metastasis. Int J Oncol 19, 913-919

43. Honjo $\mathrm{Y}$, Inohara $\mathrm{H}$, Akahani $\mathrm{S}$ et al (2000) Expression of cytoplasmic galectin-3 as a prognostic marker in tongue carcinoma. Clin Cancer Res 6, 4635-4640

44. Shimamura T, Sakamoto M, Ino Y et al (2002) Clinicopathological significance of galectin-3 expression in ductal adenocarcinoma of the pancreas. Clin Cancer Res 8, 2570-2575

45. Sciacchitano S, Lavra L, Morgante A et al (2018) Galectin-3: One Molecule for an Alphabet of Diseases, from A to Z. Int J Mol Sci 19, pii: E379

46. Castronovo V, Van Den Brule FA, Jackers $P$ et al (1996) Decreased expression of galectin-3 is associated with progression of human breast cancer. J Pathol 179, 43-48

47. Honjo $\mathrm{Y}$, Nangia-Makker P, Inohara H and Raz A (2001) Down-regulation of galectin-3 suppresses tumorigenicity of human breast carcinoma cells. Clin Cancer Res 7, 661-668

48. Pacis RA, Pilat MJ, Pienta KJ et al (2000) Decreased galectin-3 expression in prostate cancer. Prostate 44 , 118-123 
49. Brustmann H, Riss D and Naude S (2003) Galectin-3 expression in normal, hyperplastic, and neoplastic endometrial tissues. Pathol Res Pract 199, 151-158

50. Shimonishi T, Miyazaki K, Kono N et al (2001) Expression of endogenous galectin-1 and galectin-3 in intrahepatic cholangiocarcinoma. Hum Pathol 32, 302-310

51. van den Brule FA, Waltregny D, Liu FT and Castronovo $\checkmark$ (2000) Alteration of the cytoplasmic/nuclear expression pattern of galectin-3 correlates with prostate carcinoma progression. Int J Cancer 89, 361-367

52. Jin L, Riss D, Ruebel K et al (2005) Galectin-3 Expression in Functioning and Silent ACTH-Producing Adenomas. Endocr Pathol 16, 107-114

53. Shimura T, Takenaka Y, Fukumori T et al (2005) Implication of galectin-3 in Wnt signaling. Cancer Res 65, 3535-3537

54. Itoh K, Brott BK, Bae GU, Ratcliffe MJ and Sokol SY (2005) Nuclear localization is required for Dishevelled function in Wnt/beta-catenin signaling. J Biol 4, 3

55. Kang HG, Kim DH, Kim SJ et al (2016) Galectin-3 supports stemness in ovarian cancer stem cells by activation of the Notch1 intracellular domain. Oncotarget 7, 68229-68241

56. Pikarsky E, Porat RM, Stein I et al (2004) NF-kappaB functions as a tumour promoter in inflammation-associated cancer. Nature 431, 461-466

57. Davidson PJ, Davis MJ, Patterson RJ, Ripoche MA, Poirier F and Wang JL (2002) Shuttling of galectin-3 between the nucleus and cytoplasm. Glycobiology 12, 329-337

58. Arnoys EJ, Ackerman CM and Wang JL (2015) Nucleocytoplasmic shuttling of galectin-3. Methods Mol Biol $1207,465-483$

59. Nakahara S, Oka N, Wang Y, Hogan V, Inohara $\mathrm{H}$ and Raz A (2006) Characterization of the nuclear import pathways of galectin-3. Cancer Res 66, 9995-10006

60. Nakahara S, Hogan V, Inohara H and Raz A (2006) Importin-mediated nuclear translocation of galectin-3. J Biol Chem 281, 39649-39659

61. Davidson PJ, Li SY, Lohse AG et al (2006) Transport of galectin-3 between the nucleus and cytoplasm. I. Conditions and signals for nuclear import. Glycobiology $16,602-611$

62. Li SY, Davidson PJ, Lin NY, Patterson RJ, Wang JL and Arnoys EJ (2006) Transport of galectin-3 between the nucleus and cytoplasm. II. Identification of the signal for nuclear export. Glycobiology 16, 612-622

63. Kim SJ, Shin JY, Cheong TC et al (2011) Galectin-3 germline variant at position 191 enhances nuclear accumulation and activation of beta-catenin in gastric cancer. Clin Exp Metastasis 28, 743-750

64. Balan V, Nangia-Makker P, Schwartz AG et al (2008) Racial disparity in breast cancer and functional germ line mutation in galectin-3 (rs4644): a pilot study. Cancer Res 68, 10045-10050

65. Dagher SF, Wang JL and Patterson RJ (1995) Identification of galectin-3 as a factor in pre-mRNA splicing. Proc Natl Acad Sci U S A 92, 1213-1217

66. Inohara H, Akahani $S$ and Raz A (1998) Galectin-3 stimulates cell proliferation. Exp Cell Res 245, 294-302
67. Bresalier RS, Mazurek N, Sternberg LR et al (1998) Metastasis of human colon cancer is altered by modifying expression of the beta-galactoside-binding protein galectin 3. Gastroenterology 115, 287-296

68. Takenaka Y, Fukumori T and Raz A (2004) Galectin-3 and metastasis. Glycoconj J 19, 543-549

69. Raz A, Zhu DG, Hogan V et al (1990) Evidence for the role of 34-kDa galactoside-binding lectin in transformation and metastasis. Int J Cancer 46, 871-877

70. Hood JD and Cheresh DA (2002) Role of integrins in cell invasion and migration. Nat Rev Cancer 2, 91-100

71. Yoder BJ, Tso E, Skacel M et al (2005) The expression of fascin, an actin-bundling motility protein, correlates with hormone receptor-negative breast cancer and a more aggressive clinical course. Clin Cancer Res 11, 186-192

72. Kureishy N, Sapountzi V, Prag S, Anilkumar N and Adams JC (2002) Fascins, and their roles in cell structure and function. Bioessays 24, 350-361

73. Hashimoto $\mathrm{Y}$, Ito $\mathrm{T}$, Inoue $\mathrm{H}$ et al (2005) Prognostic significance of fascin overexpression in human esophageal squamous cell carcinoma. Clin Cancer Res 11, 25972605

74. Jawhari AU, Buda A, Jenkins M et al (2003) Fascin, an actin-bundling protein, modulates colonic epithelial cell invasiveness and differentiation in vitro. Am J Pathol $162,69-80$

75. Grothey A, Hashizume R, Ji H et al (2000) C-erbB-2/ HER-2 upregulates fascin, an actin-bundling protein associated with cell motility, in human breast cancer cell lines. Oncogene 19, 4864-4875

76. Hashimoto Y, Shimada Y, Kawamura J, Yamasaki S and Imamura M (2004) The prognostic relevance of fascin expression in human gastric carcinoma. Oncology 67, 262-270

77. Yamashiro S, Yamakita $Y$, Ono $S$ and Matsumura $F$ (1998) Fascin, an actin-bundling protein, induces membrane protrusions and increases cell motility of epithelial cells. Mol Biol Cell 9, 993-1006

78. Shonukan O, Bagayogo I, McCrea P, Chao M and Hempstead B (2003) Neurotrophin-induced melanoma cell migration is mediated through the actin-bundling protein fascin. Oncogene 22, 3616-3623

79. Shimura T, Takenaka Y, Tsutsumi S, Hogan V, Kikuchi A and Raz A (2004) Galectin-3, a novel binding partner of beta-catenin. Cancer Res 64, 6363-6367

80. Macfarlane SR, Seatter MJ, Kanke T, Hunter GD and Plevin R (2001) Proteinase-activated receptors. Pharmacol Rev 53, 245-282

81. Tellez C and Bar-Eli M (2003) Role and regulation of the thrombin receptor (PAR-1) in human melanoma. Oncogene 22, 3130-3137

82. Arora P, Ricks TK and Trejo J (2007) Protease-activated receptor signalling, endocytic sorting and dysregulation in cancer. J Cell Sci 120, 921-928

83. Pei D (2005) Matrix metalloproteinases target proteaseactivated receptors on the tumor cell surface. Cancer Cell 7, 207-208

84. Blackburn JS, Liu I, Coon Cl and Brinckerhoff CE (2009) A matrix metalloproteinase-1/protease activated receptor-1 signaling axis promotes melanoma invasion and metastasis. 
Oncogene 28, 4237-4248

85. Song S, Byrd JC, Mazurek N, Liu K, Koo JS and Bresalier RS (2005) Galectin-3 modulates MUC2 mucin expression in human colon cancer cells at the level of transcription via AP-1 activation. Gastroenterology 129, 15811591

86. Wilson NH and Key B (2007) Neogenin: one receptor, many functions. Int J Biochem Cell Biol 39, 874-878

87. Kim SJ, Wang YG, Lee HW et al (2014) Up-regulation of neogenin-1 increases cell proliferation and motility in gastric cancer. Oncotarget 5, 3386-3398

88. Li J, Shima H, Nishizawa $H$ et al (2018) Phosphorylation of $\mathrm{BACH} 1$ switches its function from transcription factor to mitotic chromosome regulator and promotes its interaction with HMMR. Biochem J 475, 981-1002

89. Yeh MH, Tzeng YJ, Fu TY et al (2018) Extracellular Matrix-receptor Interaction Signaling Genes Associated with Inferior Breast Cancer Survival. Anticancer Res 38, 4593-4605

90. Casini P, Nardi I and Ori M (2010) RHAMM mRNA expression in proliferating and migrating cells of the developing central nervous system. Gene Expr Patterns 10, 93-97

91. Bahrami SB, Tolg C, Peart T et al (2017) Receptor for hyaluronan mediated motility (RHAMM/HMMR) is a novel target for promoting subcutaneous adipogenesis. Integr Biol (Camb) 9, 223-237

92. Connell M, Chen $\mathrm{H}$, Jiang J et al (2017) HMMR acts in the PLK1-dependent spindle positioning pathway and supports neural development. Elife 6, pii: e28672

93. Silverman AM, Nakata $R$, Shimada $H$, Sposto $R$ and DeClerck YA (2012) A galectin-3-dependent pathway upregulates interleukin-6 in the microenvironment of human neuroblastoma. Cancer Res 72, 2228-2238

94. Regalo G, Forster S, Resende C et al (2016) C/EBPbeta regulates homeostatic and oncogenic gastric cell proliferation. J Mol Med (Berl) 94, 1385-1395

95. Vaught JB (2006) Biorepository and biospecimen science: a new focus for CEBP. Cancer Epidemiol Biomarkers Prev 15, 1572-1573

96. Kuilman T, Michaloglou C, Mooi WJ and Peeper DS (2010) The essence of senescence. Genes Dev 24, 2463-2479

97. Kim SJ, Lee HW, Gu Kang H et al (2014) Ablation of galectin-3 induces p27(KIP1)-dependent premature senescence without oncogenic stress. Cell Death Differ 21,
1769-1779

98. La SH, Kim SJ, Kang HG, Lee HW and Chun KH (2016) Ablation of human telomerase reverse transcriptase (hTERT) induces cellular senescence in gastric cancer through a galectin-3 dependent mechanism. Oncotarget 7, 57117-57130

99. Nangia-Makker P, Hogan V and Raz A (2018) Galectin-3 and cancer stemness. Glycobiology 28, 172-181

100. Ma J, Yao Y, Wang P et al (2014) MiR-152 functions as a tumor suppressor in glioblastoma stem cells by targeting Kruppel-like factor 4. Cancer Lett 355, 85-95

101. Seguin L, Kato S, Franovic A et al (2014) An integrin beta(3)-KRAS-RalB complex drives tumour stemness and resistance to EGFR inhibition. Nat Cell Biol 16, 457-468

102. Shekhar MP, Nangia-Makker $P$, Tait $L$, Miller $F$ and Raz A (2004) Alterations in galectin-3 expression and distribution correlate with breast cancer progression: functional analysis of galectin-3 in breast epithelial-endothelial interactions. Am J Pathol 165, 1931-1941

103. El Gendy H, Madkour B, Abdelaty S et al (2014) Galectin 3 for the diagnosis of bladder cancer. Arab J Urol 12, 178-181

104. Yoshii T, Inohara H, Takenaka Y et al (2001) Galectin-3 maintains the transformed phenotype of thyroid papillary carcinoma cells. Int J Oncol 18, 787-792

105. Nangia-Makker P, Balan V and Raz A (2008) Regulation of tumor progression by extracellular galectin-3. Cancer Microenviron 1, 43-51

106. Chen WS, Cao Z, Leffler H, Nilsson UJ and Panjwani N (2017) Galectin-3 Inhibition by a Small-Molecule Inhibitor Reduces Both Pathological Corneal Neovascularization and Fibrosis. Invest. Ophthalmol Vis Sci 58, 9-20

107. Glinskii OV, Sud S, Mossine VV et al (2012) Inhibition of prostate cancer bone metastasis by synthetic TF antigen mimic/galectin-3 inhibitor lactulose-L-leucine. Neoplasia 14, 65-73

108. Campo VL, Marchiori MF, Rodrigues LC and DiasBaruffi M (2016) Synthetic glycoconjugates inhibitors of tumor-related galectin-3: an update. Glycoconj J 33, 853-876

109. Zetterberg FR, Peterson K, Johnsson RE et al (2018) Monosaccharide Derivatives with Low-Nanomolar Lectin Affinity and High Selectivity Based on Combined Fluorine-Amide, Phenyl-Arginine, Sulfur-pi, and Halogen Bond Interactions. Chem Med Chem 13, 133-137 